\title{
Shaping Religious Identity on the Northern Edge of the Christianitas: Portraits of Pagans and Idolaters in the Twelfth Century Pomerania ${ }^{1}$
}

\author{
Oblikovanje verske identitete na severnem robu \\ christianitasa: podobe poganov in malikovalcev \\ $v$ Pomeraniji dvanajstega stoletja
}

\begin{abstract}
This study analyses the image of pagans and paganism in Pomerania during the first half of the twelfth century. It also analyses the relationship with idolatry known since early Christianity. The conversion of Pomeranians to Christianity took place by giving up the worship of idols and submission to the Christian faith. It was the obedience to the German ecclesiastical authorities and the Polish duke that caused the Pomeranians to be regarded as real Christians. This study shows that Pomeranian paganism appears as a Christian construct of a socio-religious identity, created to be an antithesis to Christianity.
\end{abstract}

Keywords: Pomerania, Paganism, Idolatry, Christianization, Apostasy, Crusading

Izvleček: Ta študija analizira podobe poganov in poganstva v Pomeraniji v prvi polovici dvanajstega stoletja. Analizira tudi razmerje z malikovanjem, kot je znano vse od zgodnjega krščanstva dalje. Pomeranijci so se spreobrnili v krščanstvo, s tem ko so prenehali častiti malike ter se predali krščanski veri. Zaradi svoje poslušnosti nemškim cerkvenim avtoritetam ter poljskemu vojvodi so veljali za prave kristjane. Ta študija pokaže, da je pomeranijsko poganstvo izvorno krščanski konstrukt družbeno-verske identitete, ki je bil ustvarjen kot antiteza krščanstvu.

Ključne besede: Pomeranija, poganstvo, malikovanje, pokristjanjenje, odpadništvo, križarstvo

1 This study is based on research conducted in 2021 at the Faculty of Theology, University of Copenhagen, and was supported through a grant given by the Eugen Lozovan Foundation in Copenhagen. 


\section{Introduction}

The historiography regarding the construction of a pagan identity in relation to idolatry and apostasy in medieval north is very rich. In this approach, historians have shown interest both in the theological arguments used by chroniclers to define pagan identity on the Southern Baltic coast (Dragnea 2021b; Goetz 2015, 103-118; Cusack 2011, 33-51; Ingrao and Szabo 2008; Kaljundi 2008, 113-127; Lübke 2008, 189-203; Jensen 2002, 173-193; Scior 2002), the authenticity of the Slavic mythology (Rosik 2020; Hardt 2015, 263-268; Müller-Wille 1999) and in the political, social and cultural interaction between pagans and Christians (Dragnea 2019, 7-34; Hardt 2005, 35-49; Zaroff 2003, 5-36; Petersohn 2003, 99-139; Lübke 2002, 91-110; Althoff 1999, 267-292; Hoffmann 1998, 23-49). The influence of crusading ideas in the discourse of the chroniclers (Dragnea 2021, 41-61; Dragnea 2019; von Güttner Sporzyński 2014; Gładysz 2012; Fonnesberg-Schmidt 2007; Lotter 1989, 267-306), the justification of warfare against the apostates and the forced conversion in relation to the canon law was also analysed (Jensen 2016, 227-250; Becher 2013, 23-52; Hen 2006, 33-51; Warner 2006, 11-35; Kahl 1955, 161-193, 360-401).

In the last decades historians have focused on the role of ethnicity in the development of pagan identities in Northern Europe. ${ }^{2}$ It was also analysed how the pagans became "the others « and what theoretical background accompanied this transformation. Such kind of ideas are of course debatable but one thing is certain. Articles with this topic have stimulated the latest research on pagan identity in the Latin periphery. However, in this discussion from the last two decades the influence of theology in relation to the political matters has been underappreciated. There are in fact no specialized studies dealing with apostasy and the role of canon law and ecclesiastical authority in shaping the profile of the Pomeranians. ${ }^{3}$ Therefore this article will attempt to correct the lack of discussion on church affairs as an important aspect of how the ecclesiastical writers

2 See the special thematic issue of the Journal of Medieval and Early Modern Studies 31 (2001), with special attention to the studies of Hahn, 1-37, Bartlett, 39-56, and Jordan, 165-173. A fundamental work on expansion of the Latin Christian frontiers is Bartlett (1993).

3 There are only a few studies that focus on the whole Baltic region in a broad sense: Janson 2010, 11-30; 2009, 171-191; 2005, 141-154. 
from the northern fringe of the Latin Christianity described the pagan identity. It will also explain why and how labels such as "pagans" and »apostates« were equated.

Scholars have wondered over time to which extent the image of the pre-Christian cults and beliefs was distorted. In certain cases, labels assigned to the Pomeranians as other northerners did not concern real pagans, but rather apostates. The Pomeranians had not left any tangible proof of their genuine religion. The ecclesiastical narratives on pagan practices were nothing more than motifs collected from classical literature. In a broad sense the concept is known as interpretatio Romana. ${ }^{4}$

This article will take a strong position on an ongoing historical debate about whether conversion accounts produced by Christian authors in the Middle Ages tell us anything real about the native paganism of northern Europe or are simply a concoction of tropes, clichés and literary borrowings. It will examine the question of what elements constituted the pagan identity in twelfth-century Pomerania, and how this image had been created by the ecclesiastical writers according to the canon law. They depicted Pomerania as a pagan realm beyond the Christian mental frontier, whose inhabitants were in need of salvation through conversion, even if they were already Christians. In order to decrypt the clerical information about the Pomeranians' religiosity in theory and practice, it is necessary to place the narrative within the political context of the time. It is also appropriate to explore the intellectual life of the medieval authors who wrote about the supposed Pomeranian idolatry. The condemnation of Pomeranian idolatry was not only a theological endeavour meant to strengthen the authority of the church on the Christian periphery. It could also be seen as an individual or collective attempt to interpret certain events on the basis of the political background. Therefore our investigation will focus on medieval literary perception of Pomeranian idolatry, its nature and its relation to Christianity.

4 For the interpretatio Romana of Slavic pre-Christian religion in the historiography of the last century, see Rosik 2020, 10-38. 


\section{Who were the Pomeranians?}

Pomeranians (Pomerani), who inhabited the region called Pomerania between the Oder and the Vistula, were among the most important Wendish tribes, along with the Obotrites, Luticians, and Rugians. ${ }^{5}$ The distinct character of the Wends was emphasized by chroniclers from the tenth century onwards. ${ }^{6}$ According to the eleventh-century chronicler Adam of Bremen, there were about thirteen Wendish tribes stretching over a vast territory mostly across the Elbe. For Germans, the Wends (Wenden) were speakers of Slavic languages, living in a large area between the Elbe and the Baltic Sea (Graus 1980, 74). For Scandinavians, the Wends (vinder in skaldic poetry) were neighbours living on the southern coast of the Baltic Sea (Vindland). Their eastern neighbours were called Austr-Vinðir ("East Wends") with the synonym term Loesir. This is in fact an exonym which could designate the "Wends« living close to the western boundary of Rus' (e. g. Lendians). ${ }^{7}$

\section{The Conquest and Conversion of the Pomeranians}

The earliest description of Pomeranian paganism in connection to idolatry in the twelfth century was given by a Benedictine monk known as Wolfger. He is one of the three biographers of Bishop Otto of Bamberg (d. 1139). His biography was written between 1140 and 1146 at Prüfening, a Bavarian abbey founded by Otto on 12 May 1119. ${ }^{8}$ The second biography was written between 1151 and 1159 by another clergyman named Ebo from St. Michael's Abbey in Bamberg. His source of information was Wolfger's hagiography, Otto's correspondence (eight letters, of which only three were written by the bishop) and other information from Udalricus (Ulrich), one

5 Adam of Bremen 1876, I. 1; II. 18-19; III. 19.21; IV. 13.18. For the diversity of the Wendish gens and populus and the geographical distribution of the tribes in the narratives of Adam of Bremen, see Dragnea 2021b, 12.

6 For a brief analysis of the cultural and social interactions between Germans and Wends in the second half of the tenth century, see Dragnea 2019, 5-33.

7 For the participation of the Norwegian King Harald Hardrada (d. 1066) in Yaroslav's campaign against the Poles in 1031, see Lubik 2020, 12.

8 For the inscription documenting the consecration of Prüfening Monastery in 1119 to St. George, see Brekle 2005, 8 .

Edinost in dialog 76 (2021) 2: 243-273 
of the Otto's collaborators and a priest at the church of St. Aegidius. His work contains information from the memoirs of the bishop's companions on missions in Western Pomerania (e. g. Udalricus and others). The third biography was written in 1158 by Herbord (d. 1168), a magister at the St. Michael's Abbey School in Bamberg. ${ }^{9}$

As we know, the central character of the three vitae is the missionary bishop Otto of Bamberg, the second son of a Swabian noble family. After 1082 he served at the court of Duke Władysław I Herman of Poland (1079-1102) as chaplain to Judith of Swabia, second wife of the duke and sister of the emperor Henry IV. Later Otto became chancellor of the emperor, who also appointed him as bishop of Bamberg in 1102. Otto supported the emperor in his conflict with the papacy over the issue of the Investitures. His episcopal appointment was confirmed by Pope Paschal II in 1111 (Álvarez-Pedrosa 2020, 114).

The conversion of Pomerania was carried out by Otto and his clergy, but it took place in the political context of the time. A precondition was the submission of the Pomeranians. The main urbes and civitates of Pomerania were a considerable source of wealth for the Piast dynasty. The region has been under the influence of the dynasty since the time of Mieszko I. His successor, Bolesław I (992-1025), conquered some Pomeranian strongholds up to the Baltic coast and founded a diocese at Kołobrzeg around 1000 (Buko 2007, 214).

Christianity in Poland was maintained at ecclesiastical level only in territories where the Piasts were able to exercise power. The Pomeranian nobles under Polish domination were the first to revolt. Following Mieszko II's death in 1034, the inhabitants of some dependent regions within Poland rebelled against Piast domination and the Church. This resulted in the destruction of the ecclesiastical infrastructure in Greater Poland, Silesia, and the northern parts of Lesser Poland (Berend, Urbańczyk and Wiszewski 2014, 162). The most important record comes from an anonymous author, commonly referred to as Gallus since the sixteenth century.

9 For the ecclesiastical activity of Otto described by the three authors, see Álvarez-Pedrosa 2020, 113-114; Dragnea 2015, 25-48; Morrison 1977, 131-156, here 143; Demm 1972, 49-74, here 55. 
From his narrative we find out that first bishops and then priests were targeted by the rebels. Their actions were described as a deviation from the "Catholic faith ${ }^{10}$ and therefore the death penalty for apostates was legitimate. ${ }^{11}$ However, the order in which the victims (bishops first) are presented and the category of victims (only clergy) confirms that the rebellion was not driven by a zeal against Christian doctrine, but rather had an anti-clerical character. This attitude could be explained as a sign of disobedience to ecclesiastical authorities and denial of ecclesiastical hierarchy. ${ }^{12}$ Social considerations are added to these. The payment of a tribute from certain nobles such as the Pomeranians, or tithing, would have burdened the hard life of the peasantry who would have seen the clergy as the main oppressor.

The Pomeranians and other neighbouring enemies took advantage of the internal conflicts and invaded Poland. So did the Czechs, who sacked Gniezno and Poznan. What we know is that this situation did not last long. The liberation of the occupied territories is presented as a mixture of courage and divine support. It was Duke Casimir I (1040-1058) who, with only five hundred knights ${ }^{13}$ managed to crush the rebellion and to increase his control over the territories which were occupied. The Czech, Pomeranian, and other neighbouring invaders were defeated, and the duke became the rightful ruler of all the occupied territories. ${ }^{14}$

It seems that during the centuries the Pomeranians caused a lot of trouble to the neighbours. The Poles and the Saxons were attacked mostly on land by the Pomeranian milites. According to Herbord, all soldiers were horsemen, which means that the Pomeranian ground forces consisted

10 "A fide katholica deviantes, [...] adversus episcopos et sacerdotes Dei seditionem inceperunt." (Gallus Anonymus 2003, I. 19 [78])

11 "Eorumque quosdam gladio quasi dignos peremerunt, quosdam vero quasi morte dignos viliori lapidibus obruerunt." (Gallus Anonymus 2003, I. 19 [78])

12 For the Wendish idolatry in relation to disobedience in the tenth and eleventh centuries, see Dragnea 2021b, 45-67.

13 "Et assumptis secum militibus quingentis Polonie fines introivit, ulteriusque progrediens, castrum quoddam a suis sibi redditum acquisivit.«(Gallus Anonymus 2003, I. 19 [80])

14 "Totam Poloniam a Pomoranis et Bohemicis aliisque finitimis gentibus occupatam liberavit, eamque suo dominio mancipavit." (Gallus Anonymus 2003, I. 19 [80]) 
exclusively of cavalry made up of milites. ${ }^{15}$ Since each miles received only one horse, the number of milites was given by the number of horses which his lord had (Herbordi Dialogus de vita S. Ottonis 1868, II. 23 [75]). However, the military power of the Pomeranians did not consist only of the cavalry. The Pomeranian magnates from Szczecin and Wolin possessed a remarkable fleet, which also endangered neighboring states, especially the Scandinavians. Military shipment of horses is also recorded. Perhaps the most important mention of cavalry transportation is related to the raids organized on the Norwegian coast in 1135 or 1136. According to the Icelandic politician, poet, and historian, Snorri Sturluson (d. 1249), the port settlement of Konungahella (Konghelle) was sacked by an army composed of Pomeranians and other Wendish allies who possessed a naval fleet, perhaps the Rugians. ${ }^{16}$ The Pomeranians have certainly raided Norwegian coasts since the second half of the tenth century. When they were in good shape, the Norwegian kings and jarls organized punitive raids on the Pomeranian shore of the Baltic. The German chronicler Adam of Bremen stated that around 1043, King Magnus the Good of Norway (d. 1047), St. Olav's son, ${ }^{17}$ burned the Pomeranian civitas of Wolin (Adam of Bremen 1876, II. 75, [92]).

Polish attempts to extend control of some parts of Pomerania took place in the first decade of the twelfth century. In 1109, the Polish Duke Bolesław III (r. 1107-1138) managed to capture Naclam (Nakło), one of the most important Pomeranian strongholds. Records on this famous battle are found in Gesta principum Polonorum (c. 1115), written by Gallus Anonymus to restore Bolesław's undermined authority and to legitimate his power. ${ }^{18}$ There it was stated that the defeat of the much larger Pomeranian armies was possible only with divine help. God's miraculous intervention on Bolesław's behalf meant the Christian triumph over the pagan Pomeranians. The victory was part of God's plan and took place

15 In Pomerania, the power of a nobleman was estimated by the number of horses he owned (Herbordi Dialogus de vita S. Ottonis 1868, II. 23 [75]).

16 For the raid, including the cavalry transportation, see Zaroff 2014, 6-22.

17 For the Varangians in Constantinople and Olaf's cult, see Dragnea 2020, 145-167.

18 For the narrative of Gallus Anonymus about the Piasts as the sole rightful rulers of Poland, see Dalewski 2011, 145-166. 
on a special day, namely the one of the martyr St. Lawrence. ${ }^{19}$ Since it was a miraculous battle, it was decided not by the hands of the Polish knights who bore swords and shields, but by the »hand of God «. ${ }^{20}$

In the following decades, Bolesław III sought to expand his realm in eastern and central Pomerania. Between the years 1102/1103 and 1121/1122 there are records of many attacks on Białogard, Kołobrzeg, Czarnków, Ujście, Wieleń, Wyszogród and several other Pomeranian castles. ${ }^{21}$ The inhabitants of some of these castles became Christians. According to Gallus Anonymus, after they captured Czarnków, the Poles managed to baptize many Pomeranians, including the lord of the castle. ${ }^{22}$

The Polish attacks targeted not only the northern part of Pomerania. The Polish knights crossed the Oder and marched further west. The Pomeranians were again defeated and sometime between 1119 and 1122, the dukes of western Pomerania were forced to accept dependence on Bolesław III (Wiszewski 2010, xl). This was the case of the Pomeranian duke Wartislaw I (d. 1135), who became a tributary of Bolesław. Among the commitments made by Wartislaw and other Pomeranian principes was the acceptance of baptism and the conversion of his subjects (Herbordi Dialogus de vita S. Ottonis 1868, II. 21 [74]). ${ }^{23}$ Before 1124, when Otto came to preach in Western Pomerania, few Pomeranians were baptized, including the duke and the milites from his personal guard. ${ }^{24}$ The duke,

19 St. Lawrence is known as an important figure in Ottonian proselytism. His image was linked to martyrdom, protection of the Saxon Church and the struggle against pagans and apostates (i. e. the Wends across the Elbe). He was the patron of the church monastery in Calbe, Anhalt, who was sacked by the Wends during the 983 uprising. (Dragnea 2021b, 48.101)

20 "Non humana, sed manu divina." (Gallus Anonymus 2003, III. 1 [220-227]) This is not the only case of a battle won by divine aid. The pagan Cumans who invaded Poland were also crushed as a divine intervention (Gallus Anonymus 2003, II. 19 [154-155]).

21 For the Polish military campaigns in Western Pomerania campaigns in the years 1102/1103 and 1121/1122 and capture of the Pomeranian castles, see Wybranowski 2017, 67-111.

22 "Ad fidem multos ab infidelitate revocavit, ipsumque dominum castelli de fonte baptismatis elevavit." (Gallus Anonymus 2003, II. 44 [200-201])

23 The demands of the Polish duke were sent to the Pomeranian principes through comes Paulicius. According to him, the tribute paid by the whole of Pomerania ("tota terra Pomeranorum») to Bolesław III was 300 silver marks each year. Furthermore, in time of war the Pomeranians had to support the Polish duke by creating an auxiliary army financed with arms and money. (Herbordi Dialogus de vita S. Ottonis 1868, II. 30 [87])

24 "Milites ergo, qui cum duce venerant, cathezizati statim et baptizati sunt, multique ex eis qui prius christiani fuerant." (Herbordi Dialogus de vita S. Ottonis 1868, II. 21 [74]) 
his family and a part of the nobility were no doubt Christians, but regular Pomeranians and probably some other nobles were labelled as unbelievers. Because they lived in the same community with the increduli, they were seen as a group detached from Christianity, i. e. the Church, represented by the ecclesiastical authorities. Their reintegration into it did not require a new baptism, but only confession of sins, penance, and the promise to give up everything that harmed the Christian name. ${ }^{25}$

Kołobrzeg was a suffragan of Gniezno and had only one residential bishop, Reinbern, who would have led the diocese for only seven years (1000-1007) (Krzystek 2016, 72.75). According to Thietmar, he preached among the Pomeranians (Thietmar of Merseburg 1935, VII. 72 [487]), but most likely failed to attract too many adherents, especially among the Pomeranian upper class. There are no mentions of the existence of Pomeranian Christian clerics subordinated to the diocese. The Pomeranians revolted against Polish domination, remaining outside the ecclesiastical network for more than a century. The first known attempt to bring back the Pomeranians into the Christian fold was initiated at the beginning of the second decade of the twelfth century by Bolesław III. With the approval of Pope Callixtus II (d. 1124), in 1122, a Spanish Benedictine monk known as Bernard, who was appointed as bishop of Pomerania, travelled to Pomerania to correct the "error of paganism and idolatry«. With great zeal, Bernard tried unsuccessfully to convert the Pomeranians by preaching. ${ }^{26}$ The bishop might had been active in Pomerania even earlier, since in 1120 he could have arrived at the court of Bolesław. What we know is that Bernard did not receive any kind of military assistance from Bolesław, who at the time was engaged in war with Vladimir II Monomakh of Kievan Rus' (r. 1113-1125). Bernard's target was Wolin, where he travelled as a hermit to spread the "seed of the Catholic faith with constancy ${ }^{27}{ }^{27}$ That is why we should not

25 "Ex consortio incredulorum metas christianitatis excesserant, ex quorum numero ducem ipsum fuisse constat, per confessionem et poenitentiam ecclesiae reformati sunt, promittentes se deinceps omnia quae christiano inimica sunt nomini respuere, et ea quae sunt apta sectari."(Herbordi Dialogus de vita S. Ottonis 1868, II. 21 [74])

26 »Pomeraniam adhuc gentilitatis errori deditam, zelo pietatis armatus illuc euangelizandi gratia diuertit [...] ut illos ab errore idolatriae ad uiam ueritatis reducat." (Ebbonis vita Ottonis episcopi Bambergensis 1869, II. 1 [39-40]) For the missionary activity of Bernard in Pomerania, see Masalski 2017, 59-72.

27 "Despecto habitu et nudis pedibus urbem Iulin ingreditur, ibique constanter fidei katholicae semina spargere coepit." (Ebbonis vita Ottonis episcopi Bambergensis 1869, II. 1 [40]) 
be surprised when Ebo mentions that at Wolin, Bernard was attacked by the Pomeranians when he wanted to chop down a wooden idol with an axe. The idol was worshiped as a god by the Pomeranians and wrongly mentioned by the biographer as a column dedicated to Julius Caesar, from whom the urbs had supposedly taken its name (Ebbonis vita Ottonis episcopi Bambergensis 1869, II. 2 [41]). Furthermore, his appearance barefoot and wearing poor clothes astonished the Pomeranian sacerdotes and elders of the villages where he travelled. They all considered him mad and desperate. ${ }^{28}$

\section{The Pomeranian Apostasy}

Christian ethics has been defined since late antiquity by the Church Fathers. In De rudibus catechizandis, the well-known catechetical treatise, St. Augustine of Hippo (d. 430), emphasized that a true Christian is a person who before baptism renounces any kind of non-Christian socio-cultural customs. Furthermore, he warned the new converts that certain habits and practices such as drunkenness, greed, gambling (dice-players), adultery, fornication, and the attendance of public games, will not bring salvation (Augustine 1969, 7.11). Refusal to follow the norms of proper conduct was seen as a sort of religious deviance, or theologically as a rejection of the true faith (Augustine 1969, 7.11; 25.48).

In his catechetical treatise known as De correctione rusticorum, the Iberian bishop Martin of Braga (d. 580) stressed that the integration of converts into Christianity also concerned moral behaviour. Their acceptance was not limited to baptism and basic faith (Martin of Braga 1991, 15) but was also conditioned by the renunciation of certain pagan customs such as veneration of sacred spaces or the practice of divination by birds (Ornithomancy). A person who practiced such demonic things (cultura daemonum) after baptism was labelled an idolater (Martin of Braga 1991, 9-10.16.17). In Scarapsus, a Frankish catechetical manual, the abbot Pirmin (d. 753) emphasized that obedience to God was a duty as part of »the

28 "Hiis auditis sacerdotes et seniores plebis multam inter se conquisitionem habentes aiebant: Iste insanus et desperatus est." (Ebbonis vita Ottonis episcopi Bambergensis, II. 2 [41]) 
agreement made with God during baptism«. A violation of this agreement would be regarded as a defection from the Christian faith and an association with "the devil and his works" (diaboli opera) (Pirmin 1850, 1035-1036). In Pirmin's eyes, obedience to God meant several duties, including the payment of tithes and obedience and reverence to clergy $(1850,1042.1044 .1048 .1049){ }^{29}$

Certainly, things were the same in the twelfth century. For Bernard of Clairvaux (d. 1153), the rebellious Irish were »Christians only in name, but pagans in fact", and only St. Malachy, the Archbishop of Armagh (d. 1148), could reintegrate them into Latin Christianity. ${ }^{30}$ The Pomeranians were regarded in a similar way. Most probably they were dissatisfied with the heavy tribute and tithe. Their aggressively anti-ecclesiastical attitude was based not necessarily on negative feelings towards Christian doctrine, but was rather a spontaneous act motivated by social and political reasons. The Polish presence in Pomerania did not last longer than previous decades. The Pomeranians revolted again and attacked the ecclesiastical authorities and probably Christians who were obedient to them. The Pomeranians from the two main civitates, Szczecin ${ }^{31}$ and Wolin (Ebbonis vita Ottonis episcopi Bambergensis 1869, III. 1 [72-73]), were labelled as apostates by the biographers. ${ }^{22}$ The apostasy was a casus belli for the Polish duke, who organized two main punitive campaigns across the Oder in 1124 and 1128 (Kruszewski 2018, 31).

Bolesław's objectives were to restore Christianity among the Pomeranians and to ensure political control over the western part of the region. Since

29 A similar vision was shared by Boniface (d. 754), for whom »paganiae« were certain Christian rituals practiced in proximity to the churches, »under the name of the holy martyrs and confessors". See Boniface, Epistolae, no. 56, and Karlomann's capitulary of 742, Pertz 1835, 17.

30 It is worth mentioning a study emphasizing the importance of ecclesiastical affairs in shaping the pagan barbarian identity of the Irish, Wends, Scandinavians and Orthodox Russians in the twelfth century. For instance the refusal of the Irish people to pay tithes and their »diabolical « disobedience to the Anglo-Norman lords and ecclesiastical authorities. Such kind of negative portraits were made by several ecclesiastical figure, including Bernard of Clairvaux. (Perron 2009, 467-492)

31 In 1126, when a nobleman from Szczecin named Witscacus (Wyszak) sailed to Denmark, the inhabitants of the civitate were already apostates. (Ebbonis vita Ottonis episcopi Bambergensis 1869, III. $2,[75-76])$

32 Their official conversion took place in 1124 when some of them accepted the Christian "faith and doctrine" ("fide et doctrina Domini«). For Szczecin, see Ebbonis vita Ottonis episcopi Bambergensis 1868, II. 8 [55]. For Wolin, see Herbordi Dialogus de vita S. Ottonis 1868, II. 15 [65]. 
it was considered an apostate Polish region, its permanent submission had to be justified by religious aims. The protection of Christian community and obedience to German and Polish ecclesiastical authorities were the main reasons to justify warfare. The Polish military campaigns against the Pomeranians were acts of vengeance. Moreover, this was a religious warfare promoted with zeal, which was intimately connected with the ideas of justice and punishment for disobedience to God and his servant on earth, the Polish duke. The rage of the Polish knights was justified by analogy with certain biblical passages regarding the Maccabees. Bolesław's knights who marched into Western Pomerania were depicted as the Israelite heroes from the Old Testament. In a similar manner to the Maccabees, ${ }^{33}$ the Polish duke was able to defend Poland and avenge its wounds ${ }^{34}$ inflicted by its enemies both Christians (Czechs) and pagans (Pomeranians). ${ }^{35}$ One of the most important vengeful campaigns against the apostate Pomeranians labelled as pagans ${ }^{36}$ was led by Magnus, the comes of Mazovia. Again with divine aid, having a small army, Magnus managed to kill 600 Pomeranians, to seize their booty previously stolen from Mazovia and to liberate the Mazovian captives (Gallus Anonymus 2003, II. 49 [206]).

The emotional discourse of the chronicler shows that this religious warfare was an expression of both royal power and Christian values. This was an essential element within the Polish kingship and has its explanation in the history of relations between Poland and the papacy, and of course in the ideological influence of crusading in Poland. In order to avoid ecclesiastical dependency on the Saxon church and to maintain a low level of political obedience to the Ottonians, Mieszko I placed his realm under the protection of the pope and pledged himself a vassal of Saint Peter

33 "Tandem sicut Machabeorum imitator, diviso exercitu et patrie defensor extitit et iniurie vindicator." (Gallus Anonymus 2003, II. 34 [180])

34 "Tum vero Bolezlauus in dubio magno pependit, utrum prius de recenti contumelia se debeat continuo vindicare, an ab invasoribus suam patriam liberare." (Gallus Anonymus 2003, II. 34 [180])

35 "Hoc eventu Bolezlauus cum eodem exercitu de Pomoranis se vindicare disposuit, iamque cepta via Bohemos in Poloniam exire fama precurrens innotuit." (Gallus Anonymus 2003, II, 34 [180])

36 The expeditions against the pagan Wends as acts of divine vengeance and justice influenced by the crusading ideas were analysed in Dragnea 2016, 49-82. 
in Rome. ${ }^{37}$ Pope John XV (d. 996) accepted the legitimacy of the Polish dukes for the territory they ruled. Furthermore, the pope recognized the sacred character of the Piast dynasty. From the early eleventh century onwards, the Piasts were called »natural princes" of Poland (domini naturales) (Gallus Anonymus 2003, I. 19 [80]).38 If Bolesław was chosen by God to exercise his royal prerogatives, than his regnum was also a chosen ${ }^{39}$ land beloved by God and supported by Him in certain cases. Through the association with God, Poland appears as a blessed land, whose welfare God watches over. As part of the Polish regnum, western Pomerania was also considered a sacred region through the missionary of Otto of Bamberg and the presence of ecclesiastical authorities. The campaigns against the Pomeranians, a »savage nation of pagan barbarians, ${ }^{40}$ were described as a kind of »holy wars ${ }^{41}$ meant to punish the frequent apostasy and disobedience of the Pomeranian dukes. ${ }^{42}$

The apostasy took place in both rural and urban areas, but it only lasted a few years. The integration of the Pomeranians into the Church had to be made through another conversion, which took place in the context of the punitive campaigns organized by the Polish duke. In 1128, bishop Otto managed to baptize the inhabitants of the main Pomeranian civitates. ${ }^{43}$ Most likely they remained Christians in the sense of obedience to the

37 The vassality to the Holy See and the military campaigns in Pomerania were the pillars of the Piast policy because it legitimized their rule. For the interference between the two with the crusading ideas in the first half of the twelfth century, see von Güttner Sporzynski 2011, 255-268.

38 This term was also used in the late twelfth century by Vincent of Kraków 1994, I. 1 [5].

39 The idea of divine election (chosen rulers, land and people) in connection to Israel first appears in the Early Middle Ages, when the Franks were depicted as the chosen people of »New Israel« (Garrison 2000,114-161). Over the centuries it turned out to be a powerful political tool to legitimize a reign and to strengthen the ties between the royal power and the loyal noble families. In the twelfth century, the idea of the crusaders as a chosen group appeared, by analogy with the people of Israel. (Riley-Smith 1991, 130-52)

40 This dichotomy of Christians and pagans or Christians and barbarians was used not only for the Pomeranians, but also for the Prussians and Cumans. (Gallus Anonymus 2003, III. 1 [220-225])

41 "Ad mare autem septemtrionale vel amphitrionale tres habet affines barbarorum gentilium ferocissimas naciones, Selenciam, Pomoraniam, et Pruziam, contra quas regiones Polonorum dux assidue pugnat, ut eas ad fidem convertat.« (Gallus Anonymus 2003, Prohem [12])

42 "Sepe tamen principes eorum a duce Poloniensi prelio superati ad baptismum confugerunt, itemque collectis viribus fidem christianam abnegantes contra christianos bellum denuo paraverunt." (Gallus Anonymus 2003, Prohem [12])

43 For example the inhabitants of the island of Usedom were not converted in 1124 and this is why in 1127 they were described as a separate group from the apostates in Szczecin. (Ebbonis vita Ottonis episcopi Bambergensis 1869, III. 3 [77]) 
ecclesiastical organization for at least a few decades. Not all important Pomeranians manifested their disobedience and disrespect to the German ecclesiastical authorities. According to Ebo, in 1127, the rich wife of the prefect of the wealthy civitas of Wolgast accepted with honour two priests sent by Otto (Udalricus and Albwinus). The woman showed her humility and devotion for the German clergy, washing their feet and organizing a rich meal for the two priests. Moreover, the woman offered to provide protection for the two, as they could be killed by the local magistrates, who were most likely apostates (Ebbonis vita Ottonis episcopi Bambergensis 1869, III. 7 [83-84]).

\section{The Annihilation of Pomeranian Idolatry and the Victory of the Cross}

Medieval authors, like their ancient predecessors, from whom they drew inspiration, often tended to use pejorative epithets for various peoples on the periphery of Christianity. In the twelfth century, the writers sharpened the rhetoric of paganism to describe any group or individual who was disobedient to the Church or the pope. Some sort of a mental map was developed, in which certain populations have been described (not necessarily perceived) according to the age of their Christian identity and their degree of obedience to the secular and ecclesiastical centres of power. ${ }^{44}$ We should not be surprised to see that the Pomeranian apostasy was described as evil in both theory and practice. In some cases, biographers equated terms such as gods, pagans, and idols, which were associated with biblical demons (Herbordi Dialogus de vita S. Ottonis 1868, II. 30 [87-88]; Ebbonis vita Ottonis episcopi Bambergensis 1869, II. 12 [58-59]; III. 18 [100]).

The Pomeranian attacks against Christians were seen as diabolical actions, fuelled by an idolatrous faith; the Polish reprisals were therefore legitimate because they were to divert the Pomeranians from the belief in false idols. This divine task is related to the memory of the pagan past in the

\footnotetext{
44 Such kind of mental maps were often transposed in medieval mappae mundi. For more details, see Dragnea 2021a, 726-750.
} 
narrative of Gallus Anonymus. Since the ancestors of the Piasts were »stained by error and idolatry«, the Christian Piasts were aware of the religious dimension of the "error" among their subjects and knew how to correct it ${ }^{45}$ Poland became Christian relatively late comparing to other states, and its Christianity had not yet been solidly rooted. This is why rulers like Bolesław I, who defeated the Pomeranians ${ }^{46}$ and converted them to the Christian faith, ${ }^{47}$ had a special place in the narrative of Gallus Anonymus. With the help of the pope, Bolesław I founded the diocese of Kołobrzeg around 1000, ordained bishops ${ }^{48}$ and perhaps built other churches within the diocesan limits, which are not mentioned by Gallus by name or location. ${ }^{49}$ Through Mieszko I's baptism and obedience to the Holy See, ${ }^{50}$ the Piasts were placed within Christianitas and became the earthly defenders of Christianity against the enemies of the church. The Piasts were to play a special role in God's plan on earth. Their regnum was surrounded mostly by pagan peoples, and because of that they had to fight to convert them and to expand the borders of the Christianity.

Pomerania could be conquered by the Polish knights without great difficulties. Yet its incorporation within the Polish realm was a more complex action. Bolesław III was aware of the fact that in order to be legitimate, the conquest needed the approval of the papacy. To avoid possible quarrels with the Empire, the support had to come not from Gniezno, which at that time was still a suffragan of Magdeburg, but from a German bishop who was in good relations with both the emperor and the pope. The right person for this task was none other than Otto of Bamberg, whom

45 "Memoriam oblivio vetustatis abolevit et quos error et ydolatria defedavit, memorare negligamus et ad ea recitanda, que fidelis recordatio meminit, istos succincte nominando transeamus." (Gallus Anonymus 2003, I. 3 [24])

46 "Quid igitur est necesse victorias et triumphos de gentibus incredulis nominatim recitasse, quas constat eum quasi sub pedibus conculcasse." (Gallus Anonymus 2003, I. 6 [32])

47 "Ipse namque Selenciam, Pomoraniam et Prusiam usque adeo vel in perfidia persistentes contrivit, vel conversas in fide solidavit." (Gallus Anonymus 2003, I. 6 [32])

48 According to Thietmar, the only residential bishop was Reinbern, an educated Saxon cleric from Hassegau (Thietmar of Merseburg 1935, VII. 72 [487]). His successors could have been German or even Polish »hird-bishops« who acted as the duke's advisers in ecclesiastical affairs.

49 "Quod ecclesias ibi multas et episcopos per apostolicum, ymmo apostolicus per eum ordinavit." (Gallus Anonymus 2003, I. 6 [32])

50 It has been emphasized that Mieszko's baptism is one of the clearest examples of »empirical religiosity« as the central motif for a ruler's conversion. (Steele 2020, 185-217) 
Bolesław had known since childhood and who was so dear to his father, Duke Władysław I Herman (Herbordi Dialogus de vita S. Ottonis 1868, II. $6[56])$.

In Western Pomerania, Otto preached as papal legate. Furthermore, he wanted to create a bishopric there. Most probably Bolesław sought to place the bishopric under the ecclesiastical jurisdiction of the papacy, and Otto could have lobbied for this political move. In this way Bolesław would have prevented Pomerania from becoming a suffragan of Magdeburg via Gniezno.

The missionary teams who were active in Western Pomerania were composed of German and perhaps Polish clergy. ${ }^{51}$ The entire missionary activity was coordinated by Otto. His aim was to disconnect the Pomeranians from the temples and from the "impostors « who deceived them (probably the Pomeranian priesthood). They followed "deaf and mute " gods, whose power was absent because they were nothing more than "carved images«. The Pomeranians worshiped »unclean spirits«, and their stained souls could be purified only after having received the sign of the cross (status of catechumen). ${ }^{52}$ The idols were the source of the idolatrous faith spread by the priesthood called "sorceresses" (phitonissas) and "soothsayers" (sortilegi) (Ebbonis vita Ottonis episcopi Bambergensis 1869, II. 12 [59]).

This action was nothing more than a cleansing process that targeted both symbols and humans. Otto targeted not only the temples (fanis) and idols (simulacris) but also the priests (sacerdotes) in Szczecin. Neither Herbord nor Ebo mentions that the priests were punished by the Polish knights urged on by Otto. Herbord for example stated they were punished by God (mulctato divinitus sacerdote) without explaining how the punishment took place (Herbordi Dialogus de vita S. Ottonis 1868, II. 36 [96]). In this sense, it is possible that the divine punishment was based on miraculous interventions that caused death, such as various diseases or accidents. The

51 The architects of the conquest of Pomerania were not laymen but prelates who acted as Bolesław III's close advisers (Archbishop of Gniezno, Jakub of Żnin, Bishop Aleksander of Płock, and chancellor Michał Adwaniec) (Von Güttner-Sporzyński 2011, 256).

52 "Et primo ipsis deceptoribus, diis vestris surdis et mutis, sculptilibus et immundis spiritibus qui in eis sunt, signo Crucis armati, quanto citius renunciate, fana diruite, simulachra conterite..." (Herbordi Dialogus de vita S. Ottonis 1868, II. 30 [88]) 
destruction of temples and idols and death of sacerdotes, who might have been stubborn in their own faith, was regarded as a triumph of Christianity. The »victorious Cross" was erected probably in a place that was previously considered sacred by the Pomeranians. Moreover, an entire religious infrastructure was built, which made mass baptism possible. ${ }^{53}$ This allowed the missionaries to offer catechetical instructions and then to baptize a part of the population. The clergy opposed themselves to Pomeranian idolatry, which still had supporters among both lower and upper class. The Pomeranians who had been baptized received the Holy Spirit, the sacrament of baptism which brought them a »shining ray of joy.$^{54}$ The unbaptized Pomeranians were depicted as agents of »the demon of darkness «.55 The baptized Pomeranians distinguished from the idolaters »as light from darkness" (veluti lux a tenebris) (Herbordi Dialogus de vita S. Ottonis 1868, II. 36).

The fiercest fighters against the Pomeranian idolatry were the German and Polish clergy. However, in ecclesiastical authority, Germans took the lead. This was due to the fact that the whole missionary expedition was led by Bishop Otto, who acted as a papal legate. According to the biographers, in 1124-1125 and 1128, 14 churches were founded by Otto in both western and eastern Pomerania. The churches were built along the Baltic coast and on the Oder in Pyrzyce, Szczecin, Gridiz, Wolin, Lubin Kamień, Clodona, Kołobrzeg, Białogard, Gützkow, Wolgast, and Usedom. ${ }^{56}$ The Germans came from monasteries subordinate to the diocese of Bamberg, and preached among the Pomeranians. Between June 1124 and February 1125, Bishop Otto and his companions undertook a complex missionary campaign in Pomerania. ${ }^{57}$ Before baptism, the clergy annihilated the source

53 „Victoria crucis erigitur, construuntur baptisteria, dolia humo infodiuntur, cortinis velantur, omnibusque religiose ac sancte aptatis..." (Herbordi Dialogus de vita S. Ottonis 1868, II. 36 [96])

54 "Quendam iocundum et spiritualis gratiae rutilare fulgorem." (Herbordi Dialogus de vita S. Ottonis 1868, II. 36)

55 "Quidve tenebrosus demon suis cultoribus." (Herbordi Dialogus de vita S. Ottonis 1868, II. 36)

56 The distribution of the churches founded by Bishop Otto of Bamberg has been outlined in a map and can be consulted at Rębkowski 2020, 106 (Figure 3).

57 For the missionary activity of Otto and the conquest of Pomerania, see Guth 1992, 13-23; Bartlett $1985,185-201$. 
of faith (idols) and the idolatrous network (temples or other sacred places and castles), which were interconnected..$^{58}$

The first known example of desacralization of a sacred natural space in the Baltic region goes back to the early eleventh century. Thietmar of Merseburg (d. 1018) tells us that Bishop Reinbern of Kołobrzeg (d. 1013) not only destroyed the Pomeranian temples (fana idolorum) with fire, but also desacralized the Baltic Sea. His intention was to purify the water by chasing away the demons that were living there. The purification ritual took place by sprinkling holy water on the waves and throwing four stones anointed with holy oil into them. ${ }^{59}$ Desacralization of castles are recorded not only in Pomerania but in the Eastern Baltic as well. According to Henry of Livonia, after the German knights conquered a Selonian castle (Selburg) in 1207 , the bishops who accompanied them blessed the building by sparkling holy water on its walls. This act turned the castle into a Christian sacred space. The faith of Selones in idols was "washed « from their souls through baptism, and their living space where they probably performed religious rituals, was purified (Heinrici Chronicon Lyvoniae 1874, 3.11.6, [48]).

Desacralization had considerable effects on Pomeranian society. The Pomeranian gods were defeated on both the spiritual and material battlefield. After having celebrated mass and receiving communion, Otto and his priests armed themselves with axes and hoes and destroyed the wooden idols and temples in Szczecin (Herbordi Dialogus de vita S. Ottonis 1868, II. 31 [89]). This way the demons were driven from the souls of the Pomeranians and their sacred places. Throughout this process, water played the main role. It was not only a weapon used against demons, but also a vehicle for spiritual regeneration and integration into the Christian society (Ebbonis vita Ottonis episcopi Bambergensis 1869, II. 9, [53-54]; Herbordi Dialogus de vita S. Ottonis 1868, II. 28 [84-85]). The spiritual phase is known as abrenuntiatio diaboli (Urbańczyk and Rosik 2007,

58 "Si, inquiunt, aliquid divinae virtutis haberent isti, quorum sacra et templa convelluntur, utique defenderent se."(Herbordi Dialogus de vita S. Ottonis 1868, II. 31 [89])

59 »Fana idolorum destruens incendit et mare demonibus cultum inmissis quatuor lapidibus sacro crismate perunctis et aqua purgans benedicta.« (Thietmar of Merseburg 1935, VII. 72 [487])

Edinost in dialog 76 (2021) 2: 243-273 
276). ${ }^{60}$ After baptism, the clergy aimed to strengthen the Christian faith (confessio fidei) through consolidation of the Christian doctrine and the social norms inspired by the Christianity. The architect of this plan was none other than Bishop Otto of Bamberg, a close friend of the duke's family, who contributed to his education since his childhood (Herbordi Dialogus de vita S. Ottonis 1868, II. 6 [56]).

\section{Visible and Hidden Christians}

All Christian Pomeranians were part of a single flock, but their submission to the German church and Polish duke was not always manifested in public. The core of the flock was composed of neophytes who were Christians in both theory and practice. They were obedient to the ecclesiastical authorities, attended churches and received the sacraments. This could be possible only with protection from the Pomeranian duke or from certain high-rank nobles who were loyal to him. There were also Christians who manifested their faith in secret. Most probably they did not have protection and were therefore afraid to publicly express their obedience. According to Ebo, the Pomeranian duke Wartislaw was baptized as a child while a captive in Merseburg, Saxony (Ebbonis vita Ottonis episcopi Bambergensis 1869, III. 6 [82]). Herbord described him as a »wholehearted Christian ${ }^{61}$ who received Otto with great respect and who hid his faith from his pagan subjects. ${ }^{62}$ All three biographers mentioned another well-known Christian named Domislaw, a noble from Szczecin, who was baptized in Saxony, and later became an apostate (Vita Prieflingensis 1999, II. 9 [92]; Ebbonis vita Ottonis episcopi Bambergensis 1869, II. 9 [55]; Herbordi Dialogus de vita S. Ottonis 1868, II. 27 [83]). Ebo and Herbord give us a more explicit example, that of Nedamir (Nedamer), the wealthiest

60 The generic name comes from an early ninth-century Saxon baptismal vow that was found in a monastery library in Mainz. The text within was used as an incantation to remove the devil and implicitly idolatry from a person's soul before baptism. The text mentions three Germanic pagan gods that the catechumen is to forsake. For more details, see Abrenuntiatio diaboli et prefessio fidei, Wadstein 1899, 119-121.

61 "Dux terrae Wortizlaus, toto corde christianus." (Herbordi Dialogus de vita S. Ottonis 1868, III. 3 [109])

62 "Et quia christianus erat, occulte autem propter metum paganorum, corde magis quam ore locutus, in amplexu pontificis diu pendens, alta devotione super viae causa Dei clementiam collaudat." (Herbordi Dialogus de vita S. Ottonis 1868, II. 11 [60]) 
nobleman in the civitas of Wolin, also baptized in Saxony. Although his Christianity was "clandestine«, Nedamir was described as a Christian because in 1124 he helped Bishop Otto to arrive in Szczecin and treated him with devotion (Ebbonis vita Ottonis episcopi Bambergensis 1869, II. 8 [54]; Herbordi Dialogus de vita S. Ottonis 1868, II. 26 [81]).

It must be emphasized that in Wolin it was not the Pomeranian nobility who opposed Otto's preaching of the »true doctrine«, but the "perverse council of their priests ${ }^{63}{ }^{63}$ The existence of a hierarchy within the Pomeranian priesthood is confirmed by Ebo. According to him, those responsible for the apostasy in Szczecin in 1127 were the "chiefs of the idols« (high priests), who unanimously sent the Pomeranians to perdition. ${ }^{64}$ The pontifices idolorum could refer to a sort of apostate high priests in Szczecin and Wolin, who coordinated the activity of the sacerdotes.

The idolaters appeared following the revolt of the Pomeranian nobility against the Christian authorities. When they wanted to highlight their disobedience to the Polish duke or towards the apostolic authority of Otto, the biographers labelled them as pagans or worshippers of idols (Herbordi Dialogus de vita S. Ottonis 1868, II. 30 [87-88]; Ebbonis vita Ottonis episcopi Bambergensis 1869, II. 12 [58-59]). They received these labels because they had not "submitted to the Christian law" (christianam subissent legem) (Ebbonis vita Ottonis episcopi Bambergensis 1869, III. 23 [107]). We can assume that a large part of the subjects of the Pomeranian nobles became apostates, while some remained Christians. There were also few unbaptized subjects from isolated places such as the island of Usedom. Around the year 1127 they were described as a separate group from the apostates in Szczecin. All were targeted by the German King Lothair of Supplinburg

63 From Wolin, Otto was forced to go to Szczecin, where the Pomeranian duke resided and where he could receive protection. »Sed illi prauo sacerdotum suorum consilio seducti, nullatenus sanae doctrinae praeconem recipere uolebant, quin immo de finibus suis cum ignominia eum perturbantes, ad Stetinenses ire compulerunt." (Ebbonis vita Ottonis episcopi Bambergensis 1869, II. 7 [53])

64 »Ad Stetinenses, qui a fide, ut supra diximus, apostataverant [...] Nam pontifices idolorum plebem apostatam in necem eius unanimiter concitauerant." (Ebbonis vita Ottonis episcopi Bambergensis 1869, III. 15 [95]) 
(emperor from 1133 until 1137) who, assisted by Pope Honorius II, wanted to "subdue them to the yoke of faith ${ }^{65}$

Some Pomeranian nobles could have been apostates as well. This way they would have fulfilled their obligations to their subjects more easily. The tribute paid to the Polish duke by Wartislaw was taken from each noble, who in turn collected it from his subjects. In addition, they had to pay tithes to ecclesiastical authority. Therefore, the Pomeranian subjects put pressure on their nobility, who had no choice but to follow their concerns. Through the association with the apostates, sometimes called »unbelievers", the Pomeranian duke was seen as an apostate as well.

\section{The Importance of Baptism and Catechetical Education}

Herbord stated that not only Wartislaw was a Christian, but also the milites of his personal guard, who were first catechumens (persons who received the sign of the cross), and were then baptized. ${ }^{66}$ This category depended on a series of norms of social conduct that were different from the indigenous ones. The status of catechumen involved religious training and social education in accordance with apostolic »christiane fidei et religionis doctrina«. In order to cleanse the catechumen's soul, priests would have read prayers to drive away the devil. After the catechumen had been aligned with the apostolic virtues, he could be baptized. ${ }^{67}$

To receive baptism, the Pomeranians had to prove their faith in God, which was based on knowledge of his existence (Romans 10:14). The knowledge also included the Sacraments and the Christian doctrine. This was possible only after the catechetical education. Otto probably did not impose a rigorous selection of converts, and catechesis must have been rather poor,

65 "Barbarorum fines rursum adire disposuit, tam pro apostatis ad sinum ecclesie revocandis quam etiam pro alia gente Uznoim dicta, que necdum nomen Christi audierat, iugo fidei subigenda." (Ebbonis vita Ottonis episcopi Bambergensis 1869, III. 3 [77])

66 "Milites ergo, qui cum duce venerant, cathezizati statim et baptizati sunt, multique ex eis qui prius christiani fuerant, sed ex consortio incredulorum metas christianitatis excesserant, ex quorum numero ducem ipsum fuisse constat." (Herbordi Dialogus de vita S. Ottonis 1868, II. 21 [74])

67 For more details on posthumous baptisms and catechesis in medieval Scandinavia and Rus', see Uspenskij 2009, 9-22. 
since many of the Pomeranians became apostates. The apostasy must be understood not as a total or partial renunciation of the Christian sacraments and doctrines, but as a rebellion against the ecclesiastical authorities. The Pomeranians could have been Christians in their own style. The main practice they rejected was tithing. The Pomeranian duke and other Christian nobles saw this as a crisis, which they did not want to deal with, at least for the time being. We may assume that beside tithes, the ecclesiastical authorities also collected tribute. This is the only way we can explain the nobles' fear of publicly displaying their Christian identity and their ties to ecclesiastical authorities.

The apostasy was considered a defection from faith, which was equivalent to the breakup of the "Catholic Mother Church«. A reconciliation was possible only through the »sacrament of faith«(i. e. baptism). The prayers and blessed water were used to purify the souls of apostates, allowing the infusion with »baptismal grace $\|^{68}$ According to Herbord, in 1124, Otto preached the Gospel to a large number of "ignorant « Pomeranians in Pyritz (Pyrzyce).${ }^{69}$ After the Pomeranians had accepted the "holy faith« in theory, they were instructed by the bishop and his companions for seven days on how this should work in practice. ${ }^{70}$ The catechetical training was succeeded by three days of fasting, at which point the bishop ordered them to wash their bodies in water to purify themselves and be able to receive "holy baptism «. ${ }^{71}$

68 "Deinde eos, qui a fide apostataverant, benedictione sacrati fontis et manuum impositione purificans, vivifice crucis vexillo et orationis virtute katholice matri cum gaudio reconciliavit; aliis vero baptismi gratiam et fidei sacramenta contradidit." (Ebbonis vita Ottonis episcopi Bambergensis 1869, III. 17 [17])

69 "Haec et his similia, quae inserere studio brevitatis omitto, populo rudi simpliciter euangelizante pontifice, omnis illa multitudo, quasi unus homo, fidei sanctae concordantes, illius doctrinae se commiserunt." (Herbordi Dialogus de vita S. Ottonis 1868, II. 15 [65])

70 "At ille cum clericis et sacerdotibus 7 diebus eos cathezizans, et de omnibus quae christianae religioni conveniebant." (Herbordi Dialogus de vita S. Ottonis 1868, II. 15 [65])

71 "Diligentissime instruens, indicto trium dierum ieiunio, iussit, ut corpora sua balneis mundarent, et lotis albisque induti vestibus, mundo corde et corpore mundoque habitu ad sanctum baptisma concurrerent." (Herbordi Dialogus de vita S. Ottonis 1868, II. 15 [65]) In other cases, catechetical instruction included the concept of peace, certain specifications about Christian feasts, Jesus, apostles, saints, martyrs, and the Christian calendar (Herbordi Dialogus de vita S. Ottonis 1868, II. 17 [67]). For more details on how the baptism was organized and officiated in Pomerania at the urging of Otto, see Herbordi Dialogus de vita S. Ottonis 1868, II. 16 [65-67]. 
The Pomeranians of Wolin were ignorant as animals because they had no knowledge of their creator, about whom Otto preached the sacra ver$b a .^{72}$ Since they worshiped material things with no spiritual powers (i. e. wooden idols), the Pomeranians could be compared to the "naive beasts". Due to the lack of spiritual essence they were unable to follow God's path in a rational way. ${ }^{73}$ Most likely this depiction is related to the medieval perception of memory. ${ }^{74}$ Since the man was created by God in his own image (Genesis 1:27), he should always remember his Creator, to whom he should be grateful for his existence. A true Christian was a good man, who, according to Augustine, was defined by three distinct "powers« of the soul: memory (memoria), intellect (intelligentia), and will (voluntas). Augustine also believed that even though the three "powers" are distinct, they have only one (spiritual) essence. Of course, for Augustine and other theologians this was an image of the Holy Trinity. This association was discussed in the thirteenth century by theologians such as Duns Scotus. ${ }^{75}$

\section{The Pomeranian Church: the apple of discord between Germans, Poles and the Papacy}

Two years before Bolesław III's death, the archdiocese of Gniezno became independent of Magdeburg. ${ }^{76}$ In 1140, Pope Innocent II founded the diocese of Wolin (later moved to Cammin; today Kamień Pomorski), which was placed under the protection of the see of the St. Peter. ${ }^{77}$ The first episcopal see was the church of St. Adalbert at Wolin. Its first bishop was Adalbert of Pomerania, a former chaplain of Otto who assisted him in the missionary tours. Preserving the ecclesiastical independence of his

72 "Absque noticia creatoris sui omnis homo pecus est." (Ebbonis vita Ottonis episcopi Bambergensis 1869, III. 11 [57]; 25 [139].

73 »Pro ignorantia creatoris et cultu rei insensibilis comparatos iumentis insipientibus et similes factos illis, ad rectum tramitem perduxit et rationabile Deo vivo obsequium exhibere edocuit." (Ebbonis vita Ottonis episcopi Bambergensis 1869, II. 11 [57])

74 For the relationship of the neophytes to the past in the medieval Baltic region, based on both written sources and archaeological material, see Ščavinskas 2017, 354-383.

75 For the Augustinian notion of the mind in connection to the Holy Trinity, see van den Bercken 2015, 199-240.

76 For the conflict between Magdeburg and Gniezno for primacy over the Polish church in the $1130 \mathrm{~s}$ and the papal bull Ex commisso nobis, see Kosonowski 2014, 41.

77 For the context in which the bishopric as founded by Pope Innocent II, see Labuda 1992, 15-28. 
bishopric seems to be a hard task after the death of Innocent II in 1143. Since Otto I, Pomerania was under the jurisdiction of the archbishopric of Magdeburg. Therefore, the German claims materialized a few years later. In the crusader army led by the Margrave Albert the Bear of the North March (d. 1170) in the so-called Wendish Crusade of 1147, were several prelates from Magdeburg, including its Archbishop Frederick and Bishop Anselm of Havelberg (papal legate), who sought for a pretext to place the Pomeranian diocese under his jurisdiction (Lees 2015, 289).

By the 1140s, the main Pomeranian civitates - Wolin and Szczecin - had already been integrated into the ecclesiastical network. The Christian identity of Szczecin was confirmed by Vincent of Prague (d. 1170), the author of Annales Palidenses, written at the Premonstratensian monastery of Pöhlde. According to him, during the Wendish Crusade of 1147, a compact group detached from the crusader army led by Albert the Bear, who attacked Demmin. ${ }^{78}$ The crusaders from this group, probably Bohemians led by Bishop Henry of Olomouc, marched to "pagan« Szczecin aiming to capture it. ${ }^{79}$ Unfortunately for those who manipulated them in this regard, Szczecin was already Christian. ${ }^{80}$ Residents were extremely surprised to discover that they were attacked by manipulated knights bearing the sign of the cross. ${ }^{81}$ To avoid an unforeseen attack, they placed banners with the sign of the cross on the walls of the fortress. Furthermore, they opened the doors and Bishop Adalbert of Pomerania, who converted the Pomeranians together with Otto, questioned the Saxons about their unwarranted attack. ${ }^{82}$ The bishop was puzzled why swords, and not preaching,

78 Demmin (Dimine) was a Circipanian civitas, located on Peene, on the eastern ecclesiastical border of Hamburg- Bremen, in western Pomerania. According to Vincent, it belonged to the Billung March. (Dragnea 2021b, 14-15)

79 "Dominus autem Henricus, Moraviensis episcopus, pro nomine Christi cruce assumpta cum plurimis Saxoniae episcopis et plurima Saxonum militia ad fidem christianam pro convertendis Pomeranis Pomeraniam adiit.«(Vincenti Pragensis Annales 1861, 663)

80 „Verum ubi ad metropolim eorum Stetin nomine perveniunt, illud prout possunt armata militia circumdant." (Vincenti Pragensis Annales 1861, 663)

81 "Pro nomine Christi cruce assumpta, cum plurimis Saxonie episcopis et plurima Saxonum militia." (Vincenti Pragensis Annales 1861, 663)

82 "Pomerani autem cruces super castrum exponentes, legatos suos una cum episcopo suo nomine Alberto, quem domnus felicis memorie Otto Bambergensis ecclesie episcopus, qui primo eos ad fidem christianam convertit, eis dederat, ad eos mittunt: quare sic armata manu venerint, causam exquirunt."(Vincenti Pragensis Annales 1861, 663) 
were used to strengthen the supposed weak faith of the Pomeranians. ${ }^{83}$ Hostilities were avoided through diplomacy of Bishops Henry of Olomouc and Adalbert of Pomerania, but the key point was the public affirmation of the Pomeranian duke Ratibor I (r. 1135-1156) of the Christian faith. ${ }^{84}$

\section{Conclusion}

The ecclesiastical authorities condemned Pomeranian idolatry because its source of faith was evil. As in Christianity, faith was the central element that legitimized idolatry. This acted in both theory and practice. Adherence to the Christian faith meant obedience to secular and ecclesiastical authorities, and this had to be publicly acknowledged. Adherence to the faith in idols meant the opposite, namely disobedience. Most probably, Church property in Pomerania did not enjoy the same status as in Poland or the Empire and was regularly expropriated by the Pomeranian apostate nobles. The Pomeranian apostasy was associated with demonic disobedience and its consequences. God's servants on Earth were the ecclesiastical authorities, and the denial of their authority meant a sort of Satanic rebellion against Him and His divine order.

Ecclesiastical writers often mentioned that the Pomeranians relapsed from the true faith and joined in idolatry. For the Christian writers the Pomeranians were true heathens worshipping genuine gods or Christ alongside other gods. The Pomeranian idols were the biblical idols whose power came from demonic spirits. The Pomeranians left no written testimonies regarding their cults and beliefs. The narratives on their so-called paganism and idolatry were nothing more than "ancient superstitions" rooted in classical Greco-Roman ethnographic works. Paganism became associated not only with the superstitions practiced by improperly converted Pomeranians, but also with a variety of other immoral behaviours, lack of discipline, and above all disobedience. These were presented

83 "Si pro confirmanda fide christiana venerunt, non armis sed praedicatione episcoporum hoc eos facere debuisse referent."(Vincenti Pragensis Annales 1861, 663)

84 "Sed quia Saxones potius pro auferenda eis terra quam pro fide christiana confirmanda tantam moverant militiam, episcopi Saxoniae hoc audientes cum Ratibor principe et cum Alberto terrae illius episcopo consilio de his, quae ad pacem sunt, habito, plurimis amissis militibus, una cum principibus suis ad propria redeunt.« (Vincenti Pragensis Annales 1861, 663) 
in the literature as public testimonies for the Christian audience. The aim of the clergy was to justify the military campaigns and forced conversion in Western Pomerania, meant for bringing the relapsed apostates into the fold.

The missionary expeditions in Western Pomerania were experiences with the demonic. The Pomeranians were described as pagans because they worshiped idols. Their idolatry was justified by demonic rituals condemned by Church officials over the centuries, which were well known in the Christianitas. To be labeled as a pagan, it was necessary to worship idols in temples and to attend certain sacred places. These were not separate from the temples, but connected to them (sacra et templa). This connection ensured the integration of the Pomeranian community with the sacrum. Furthermore, the label also implied the connection of the cult practices with magic. A pagan had to practice various rituals and perform sacrifices to the idols according to the local custom. As the primary sources have shown us, the Pomeranian idolatry was far from a primitive, unorganized cult. The priestly attributions also included socio-political aspects that were exercised according to the hierarchy. The Pomeranian priests were well organized and prominent in religious matters, but still not appropriately disciplined. Their rituals contradicted canon law. 


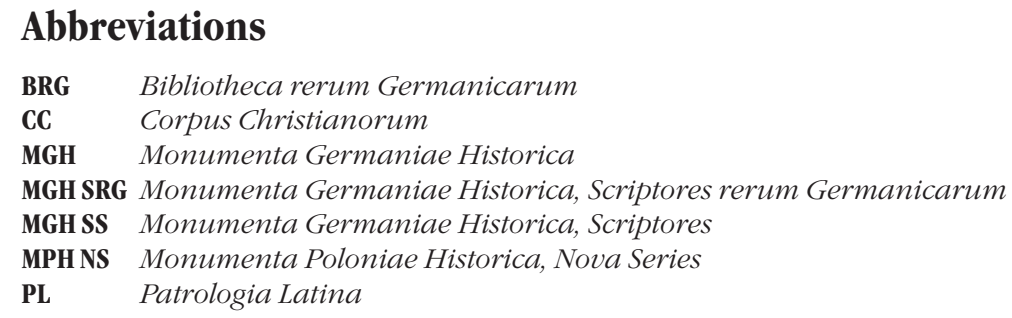

\section{References}

\section{Primary sources}

Álvarez-Pedrosa, Juan Antonio. 2020. Sources of Slavic Pre-Christian Religion. Leiden: Brill.

Bauer, I. B., ed. 1969. Augustine: De catechizandis rudibus. CC, Series latina 46. Turnhout: Brepols.

Brekle, Herbert E. 2005. Die Prüfeninger Weiheinschrift von 1119. Eine paläographisch-typographische Untersuchung. Regensburg: Scriptorium.

Holtzmann, R., ed. 1935. Thietmar of Merseburg: Chronicon. n.s. 9. MGH SRG. Berlin: Weidmannsche Buchhandlung.

Jaffe, Philip, ed. 1869. Ebbonis vita Ottonis episcopi Bambergensis. BRG. Berlin: Weidmannos.

Köpke, Rudolf, ed. 1868. Herbordi Dialogus de vita S. Ottonis. MGH. Hannover: Impensis Bibliopolii Hahniani.

Lappenberg, J. M., ed. 1876. Adam of Bremen: Adami gesta Hammaburgensis ecclesiae Pontificum. MGH SRG. Hannover: Impensis Bibliopolii Hahniani.

Migne, J-P., ed. 1850. Pirmin: Scarapsus. PL, 89. Paris: Migne.

Naldini, Mario, ed. 1991. Martin of Braga: Contro le superstizioni: Catechesi al popolo (De correctione rusticorum), Biblioteca Patristica 19. Florence: Nardini Editore.

Pertz, G. H., ed. 1874. Heinrici Chronicon Lyvoniae. MGH. Hannover: Impensis Bibliopolii Hahniani.
- - -. 1835. Boniface: Epistolae no. 56, and Karlomann's capitulary of 742 , Capitularia regum Francorum. MGH Leges in folio, 1. Hannover: Hahn.

Petersohn, Jürgen. 1999. Vita Prieflingensis: Die Prüfeninger Vita Bischof Ottos I. von Bamberg nach der Fassung des Großen Österreichischen Legendars. MGH SRG. Hannover: Hahnsche Buchhandlung.

Plezia, Marian. 1994. Vincent of Kraków. Magistri Vincentii dicti Kadtubek Chronica Polonorum. MPH NS. Cracow: Polska Akademia Umiejętności.

Schaer, Frank and Knoll, Paul W., eds. 2003. Gallus Anonymus: Gesta Principum Polonorum. Budapest and New York: CEU Press.

Wadstein, E. 1899. Abrenuntiatio diaboli et prefessio fidei, Kleinere altsächsische Sprachdenkmäler. In: Niederdeutsche Denkmäler 6, 119-121. Norden: Soltau.

Wattenbach, Wilhelm. 1861. Vincenti Pragensis Annales. MGH SS 17, 658-683. Hanover: Impensis Bibliopolii Hahniani. 


\section{Secondary literature}

Althoff, Gerd. 1999. Saxony and the Elbe Slavs in the Tenth Century. In: The New Cambridge Medieval History. Vol. 3, ed. Timothy Reuter, 267-292. Cambridge: Cambridge University Press.

Bartlett, Robert. 1985. The Conversion of a Pagan Society in the Middle Ages, History 70/229: 185-201.

- - -. 1993. The Making of Europe: Conquest, Colonization, and Cultural Change, 950-1350. Princeton: Princeton University Press.

- - - 2001. Medieval and Modern Concepts of Race and Ethnicity. Journal of Medieval and Early Modern Studies 31/1: 39-56.

Becher, Matthias. 2013. Der Prediger mit eiserner Zunge. Die Unterwerfung und Christianisierung der Sachsen durch Karl den Großen. In: Hermann Kamp and Martin Kroker, eds. Schwertmission, 23-52. Paderborn: Ferdinand Schöningh.

Berend, Nora, Przemysław Urbańczyk and Przemysław Wiszewski. 2014. Central Europe in the High Middle Ages: Bohemia, Hungary and Poland, c. 900-c. 1300. Cambridge: Cambridge University Press.

Buko, Andrzej. 2007. The Archaeology of Early Medieval Poland: Discoveries Hypotheses - Interpretations. Leiden/ Boston: Brill.

Cusack, Carole. 2011. Pagan Saxon Resistance to Charlemagne's Mission: 'Indigenous' Religion and 'World' Religion in the Early Middle Ages. The Pomegranate 13/1: 33-51.

Dalewski, Zbigniew. 2011. A New Chosen People? Gallus Anonymus's Narrative about Poland and its Rulers. In: Ildar H. Garipzanov, ed. Historical Narratives and Christian Identity on a European Periphery: Early History Writing in Northern, East-Central, and Eastern Europe (c. 1070-1200), 145-166. Turnhout: Brepols.
Demm, Eberhard. 1972. A program for revolution in a medieval monastery: Herbord's Vita of Bishop Otto of Bamberg. Studia monastica 14: 49-74.

Dragnea, Mihai. 2015. Otto din Bamberg: Reformă Monastică și Misiune Apostolică. In: I. Căzan and B. Mateescu, eds. Timp, societate și identitate culturală. ,Miniaturi istorice, 25-48. Cluj/Napoca: Academia Română/Centrul de Studii Transilvane.

- - -. 2016. Divine Vengeance and Human Justice in the Wendish Crusade of 1147. Collegium Medievale 29: 49-82.

- - -. 2019. The Saxon expeditions against the Wends and the foundation of Magdeburg during Otto I's reign. The Romanian Journal for Baltic and Nordic Studies 11/2: 7-34.

- - -. 2019. The Wendish Crusade, 1147: The Development of Crusading Ideology in the Twelfth Century. London: Routledge.

- - -. 2019. Verbal and Non-Verbal Communication Between Germans and Wends in the Second Half of the Tenth Century. Journal of the Institute of Latvian History 110/2: 5-33.

- - -. 2020. The Cult of St. Olaf in the Latin and Greek Churches between the Eleventh and Twelfth Centuries. Hiperboreea 7/2: 145-167.

- - - 2021a. Constructions of Christian Identity in the Northern Periphery: The Sawley World Map in Twelfth-Century England. The Journal of Ecclesiastical History 72/4: 726-750.

- - -. 2021b. Christian Identity Formation Across the Elbe in the Tenth and Eleventh Centuries. New York: Peter Lang.

- - -. 2021c. Crusade and Colonization in the Wendish Territories in the Early Twelfth Century: An Analysis of the So-Called Magdeburg Letter of 1108. Mediaevalia 42: 41-61.

Fonnesberg-Schmidt, Iben. 2007. The Popes and the Baltic Crusades: 1147-1254. Leiden: Brill. 
Garrison, Mary. 2000. The Franks as the New Israel? Education for an Identity from Pippin to Charlemagne. In: Yitzhak Hen and Matthew Innes, eds. The Uses of the Past in the Early Middle Ages, 114-16. Cambridge: Cambridge University Press.

Gładysz, Mikołaj. 2012. The Forgotten Crusaders: Poland and the Crusader Movement in the Twelfth and Thirteenth Centuries. Leiden: Brill.

Goetz, Hans-Werner. 2015. Die Slawen in der Wahrnehmung Thietmars von Merseburg zu Beginn des 11. Jahrhunderts. Lětopis 2: 103-118.

Graus, Frantiček. 1980. Die Nationenbildung der Westslawen im Mittelalter. Sigmaringen: Jan Thorbecke.

Guth, Klaus. 1992. The Pomeranian Missionary Journeys of Otto I of Bamberg and the Crusade Movement of the Eleventh to Twelfth Centuries. In: The Second Crusade and the Cistercians, ed. M. Gervers, 13-23. New York: Palgrave.

Hahn, Thomas. 2001. The Difference the Middle Ages Makes: Color and Race before the Modern World. Journal of Medieval and Early Modern Studies 31/1: 1-37.

Hardt, Matthias. 2005. The Limes Saxoniae as Part of the Eastern Borderlands of the Frankish and Ottonian-Salian Empire. In: Florin Curta, ed. Borders, Barriers, and Ethnogenesis: Frontiers in Late Antiquity and the Middle Ages, 35-49. Turnhout: Brepols.

- - -. 2015. Gentilreligion und christliche Mission bei den Sorben (10-12 Jahrhundert). In: Christiane Ruhmann and Vera Brieske, eds. Dying Gods: Religious Beliefs in Northern and Eastern Europe in the Time of Christianisation. Neue Studien zur Sachsenforschung, 5, 263-268. Hannover: BWH GmbH.

Hen, Yitzhak. 2006. Charlemagne's Jihad, Viator 37: 33-51.
Hoffmann, Erich. 1998. Beiträge zur Geschichte der Obotriten zur Zeit der Nakoniden. In: E. Hübner, E. Klug, and J. Kusber, eds. Zwischen Christianisierung und Europäisierung, 23-49. Stuttgart: Franz Steiner.

Ingrao, Charles W., and Szabo, Franz A.J. 2008. The Germans and the East. West Lafayette: Purdue University Press.

Janson, Henrik. 2005. Making Enemies. Aspects on the Formation of Conflicting Identities in the Southern Baltics around the Year 1000. In: Tuomas Lehtonen et al., eds. Medieval History Writing and Crusading Ideology, 141-154. Helsinki: Finnish Literature Society.

- - -. 2009. Pagani and Christiani - Cultural Identity and Exclusion Around the Baltic in the Early Middle Ages. In: Jörn Staecker, ed. The Reception of Medieval Europe in the Baltic Sea Region, 171-191. Visby: Gotland University Press.

- - -. 2010. What Made the Pagans Pagans? In: Stepanov and G. Kazakov, eds. Medieval Christianitas. Different Regions, 'Faces', Approaches, 11-30. Sofia: Voenno izdatelstvo.

Jensen, Kurt Villads. 2002. The Blue Baltic Border of Denmark in the High Middle Ages: Danes, Wends and Saxo Grammaticus. In: David Abulafia and Nora Berend, eds. Medieval Frontiers: Concepts and Practices, 173-193. Aldershot: Ashgate.

- - -. 2016. Holy War - Holy Wrath: Baltic Wars between Regulated Warfare and Total Annihilation around 1200. In: Kirsi Salonen and Sari KatajalaPeltomaa, eds. Church and Belief in the Middle Ages: Popes, Saints, and Crusaders, 227-250. Amsterdam: Amsterdam University Press.

Jordan, William Chester. 2001. Why Race? Journal of Medieval and Early Modern Studies 31/1: 165-173.

Kahl, Hans-Dietrich. 1955. Compellere intrare im Lichte hochmittelalterlichen Missions- und Völkerrechts. Zeitschrift für Ostforschung 4: 161-193; 360-401. 
Kaljundi, Linda. 2008. Waiting for the Barbarians: Reconstruction of Otherness in the Saxon Missionary and Crusading Chronicles, 11th -13th Centuries. In: Erik Kooper, ed. The Medieval Chronicle, 113-127. Amsterdam: Rodopi.

Kosonowski, Mateusz. 2014. Gniezno czy Magdeburg? Ze studiów nad rywalizacją o prymat nad organizacją diecezjalna Kościoła katolickiego w Polsce w latach 30. XII wieku. Nasza Przesztość. Studia z dziejów Kościoła i kultury katolickiej w Polsce 121: 5-56.

Kruszewski, Tomasz. 2018. Wpływ wojen polsko-pomorskich na status prawny Pomorza do XIII wieku. Studia z Dziejów Państwa i Prawa 21: 15-42.

Krzystek, Andrzej. 2016. Depositio episcoporum - katalog biskupów misyjnych, pomorskich, kamieńskich i szczecińsko-kamieńskich. Colloquia Theologica Ottoniana 1: 69-89.

Labuda, Gerard. 1992. Początki biskupstwa wolińskiego w bulli papieża Innocentego II z dnia 14 X 1140 roku. Archiwa, Biblioteki i Muzea Kościelne 61: 15-28.

Lees, Jay T. 2015. 'Why Have You Come with Weapons Drawn?' The Leaders of the Wendish Campaign of 1147. In: J. T. Roche and J. M. Jensen, eds. The Second Crusade: Holy War on the Periphery of Latin Christendom, 273-301. Turnhout: Brepols.

Lotter, Friedrich. 1989. The Crusading Idea and the Conquest of the Region East of the Elbe. In: Robert Bartlett and Angus MacKay, eds. Medieval Frontier Societies, 267-306. Oxford: Clarendon Press.

Lubik, Maciej. 2020. Haraldr Sigurðarson's arrival in Rus' and his participation in the campaign against Poland in 1031. Historisk tidsskrift 99/1: 6-20.

Lübke, Christian. 2002. Zwischen Polen und dem Reich. Elbslawen und Gentilreligion. In: Michael Borgolte, ed. Polen und Deutschland vor 1000 Jahren. Die Berliner Tagung über den "Akt von Gnesen «, 91-110. Berlin: Akademie.
- - -. 2008. Christianity and Paganism as Elements of Gentile Identities to the East of the Elbe and Saale Rivers. In: I. H. Garipzanov, P. Geary, and P. Urbanczyk, eds. Franks, Northmen, and Slavs: Identities and State Formation in Early Medieval Europe, 189-203. Turnhout: Brepols.

Masalski, Robert. 2017. Metody misyjne Bp. Bernarda Hiszpana I Bp. Ottona z Bambergu. Analiza porównawcza. Colloquia Theologica Ottoniana 1: 59-72.

Morrison, Karl F. 1977. The Structure of Holiness in Othloh's Vita Bonifatii and Ebo's Vita Ottonis. In: Kenneth Pennington and Robert Somerville, eds. Law, Church and Society. Essays in Honor of Stephan Kuttner, 131-156. Philadelphia: University of Pennsylvania Press.

Müller-Wille, Michael. 1999. Opferkulte der Germanen und Slawen. Stuttgart: Theiss.

Perron, Anthony. 2009. The Face of the 'Pagan': Portraits of Religious Deviance on the Medieval Periphery. Journal of The Historical Society 9/4: 467-492.

Petersohn, Jürgen. 2003. König Otto III. und die Slawen an Ostsee, Oder und Elbe um das Jahr 995. Frühmittelalterliche Studien 37/1: 99-139.

Rębkowski, Marian. 2020. The Beginnings of Christianity in Pomerania. In: I. Kąkolewski, Ch. Lübke and P. Urbańczyk, eds. The Dawning of Christianity in Poland and across Central-Eastern Europe: History and the Politics of Memory, 91-109. Berlin: Peter Lang.

Riley-Smith, Jonathan. 1991. The First Crusade and Idea of Crusading. Philadelphia: University of Pennsylvania Press.

Rosik, Stanisław. 2020. The Slavic Religion in the Light of 11th-and 12th-Century German Chronicles (Thietmar of Merseburg, Adam of Bremen, Helmold of Bosau): Studies on the Christian Interpretation of Pre-Christian Cults and Beliefs in the Middle Ages. Leiden and Boston: Brill. 
Ščavinskas, Marius. 2017. The Christianisation of the Past (the Example of the Baltic Society in High Middle Ages). Quaestiones Medii Aevi Novae 22: 354-383.

Scior, Volker. 2002. Das Eigene und das Fremde: Identität und Fremdheit in den Chroniken Adams von Bremen, Helmolds von Bosau und Arnolds von Lübeck. Berlin: De Gruyter.

Steele, Philip E. 2020. Homo religiosus: the phenomenon of Poland's Mieszko I. In: I. Kąkolewski, Ch. Lübke and P. Urbańczyk, eds. The Dawning of Christianity in Poland and across Central-Eastern Europe: History and the Politics of Memory, 185-217. Berlin: Peter Lang.

Urbańczyk, Przemysław and Rosik, Stanisław. 2007. The Kingdom of Poland, with an Appendix on Polabia and Pomerania between paganism and Christianity. In: Nora Berend, ed. Christianization and the Rise of Christian Monarchy: Scandinavia, Central Europe and Rus' c. 900-1200, 263-318. Cambridge: Cambridge University Press.

Uspenskij, Fjodor. 2009. The Baptism of Bones and Prima Signatio in Medieval Scandinavia and Rus'. In: L. P. Słupecki and J. Morawiec, eds. Between Paganism and Christianity in the North, 9-22. Rzeszów: WUR.

Van den Bercken, H. L. 2015. John Duns Scotus in two minds about the Powers of the Soul. Recherches de théologie et philosophie médiévales 82/2: 199-240.
Von Güttner Sporzynski, Darius. 2011. Poland and the Papacy Before the Second Crusade. In: Michel Balard, ed. $L a$ Papauté et les croisades / The Papacy and the Crusades: Actes du VIIe Congrès de la Society for the Study of the Crusades and the Latin East/ Proceedings of the VIIth Conference of the Society for the Study of the Crusades and the Latin East, 255-268. Farnham: Ashgate.

- - -. 2014. Poland, Holy War, and the Piast Monarchy, 1100-1230. Turnhout: Brepols.

Warner, David A. 2006. Saints, Pagans, War, and Rulership in Medieval Germany. In: Robert C. Figueira, ed. Plenitude of Power: The Doctrines and Exercise of Authority in the Middle Ages: Essays in Memory of Robert Louis Benson, 11-35. Aldershot: Ashgate.

Wiszewski, Przemysław. 2010. Domus Bolezlai: Values and Social Identity in Dynastic Traditions of Medieval Poland (c. 966-1138). Leiden/Boston: Brill.

Wybranowski, Dariusz. 2017. Jeszcze raz o taktyce wojen pomorskich Bolesława Krzywoustego oraz okolicznościach ich finału. Przeglad Zachodniopomorski 2: 67-111.

Zaroff, Roman. 2003. Study into the Sociopolitical History of the Obodrites. Collegium Medievale 16: 5-36.

- - -. 2014. Slavic Raid on Konungahella. Collegium Medievale 27: 6-22. 